Book review

\title{
The God delusion
}

Richard Dawkins

New York, Houghton Mifflin Company, 2006

\section{Renato Zamora Flores*}

* PhD. Professor, Department of Genetics, Universidade Federal do Rio Grande do Sul (UFRGS), Porto Alegre, RS, Brazil.

“The achievements of theologians don’t do anything, don’t affect anything, don’t mean anything. What makes anyone think that “theology” is a subject at all?” (Richard Dawkins) ${ }^{1}$

On September 15, 2001, only 4 days after the terrorist attack to the World Trade Center in New York, Richard Dawkins - evolutionary biologist, 65 years, professor of public understanding of science at the University of Oxford - published an incisive article on the renowned English newspaper The Guardian, with the impressive title “Religion’s misguided missiles,” where he stated:

“Those people were not mindless and they were certainly not cowards. On the contrary, they had sufficiently effective minds braced with an insane courage, and it would pay us mightily to understand where that courage came from. It came from religion. Religion is also, of course, the underlying source of the divisiveness in the Middle East... To fill a world with religion, or religions of the Abrahamic kind, is like littering the streets with loaded guns. Do not be surprised if they are used". 2 
Without losing the courage and creativity that have characterized Dawkins since his first book, The selfish gene, ${ }^{3}$ launched 30 years ago, the British scientist now launches a dense and solid critical work on the logical and scientific bases of religious thinking: The God delusion. The title is a bit more sarcastic than it looks. As the author explains in the introduction, the term refers to a persistent and false belief, maintained even when confronted with strong contrary evidence, especially seen as a symptom of a psychiatric disease. This is an appropriate definition for delirium.

There are no doubts that it is scientifically impossible to unmistakably demonstrate the inexistence of any entity, whether it is God, angels, fairies or Bigfoot. Dawkins, however, presents a more coherent proposal from the scientific perspective. He suggests a comparative reflection between two models. The traditional model, called "divine hypothesis," can be thus described: there is a superhuman and supernatural intelligence that deliberately designed and created the universe and everything on it, including ourselves.

Next, he proposes an alternative hypothesis, which is explained over the 10 chapters of the book: the forms of creative intelligence, with enough complexity to project anything, only came to life after a long process of gradual evolution. If creative intelligences came to life well after the universe started, they cannot be responsible for its creation.

\section{COMPARISON OF HYPOTHESES}

Using an uncommon clarity among contemporary scientists, Dawkins examines the main arguments for both hypotheses throughout his work. It is clear that he is defending his theoretical position, but this is not, per se, a scientific error. What he wishes to investigate is whether the arguments respect logical rules and do not falsify or omit information; with this regard, the author is very efficient.

By examining the arguments on the existence of God, the first to fall in the battlefield is Saint Thomas Aquinas, who, in the $13^{\text {th }}$ century, formalized the discussion on this theme. In fact, in a contemporary assessment of the saint's argumentation, Dawkins exposes its fragility. Of the five 
arguments to justify the existence of the divinity, three (proof from motion, proof for efficient causation and proof from contingency) are different versions of the same idea: nothing moves without a cause, nothing is caused by itself, and there was a time when there were no physical objects. God was obviously the creator of everything... But the idea of God is not immune to that regression to the past: If there was a time when there was nothing, where does the divinity come from, Dawkins asks? In addition, assuming, for the benefit of the discussion, that there was a creator, it does not mean that it has any of the mystical properties attributed to Abraham's God: omniscience, kindness, creativity, understanding of prayers, forgiveness of sins and intimate knowledge of the mind of all human beings.

The fourth argument is not even an argument. It is based on the idea that we perceive that certain beings are more beautiful, more noble, etc., than others. Therefore, there must be something absolute in terms of beauty, nobility or any other virtue, and this something is God. Nowadays, we are not able to evaluate how that argument seemed logical more than 600 years ago. It is currently very foolish, since, according to Dawkins, we could argue that people vary with regard to the bad smell they exhale. Therefore, there must be a lonely stinky being, as the ultimate perfection in bad smell, and this being could be called God.

The fifth and last argument is the most modern of all, as it deals with the "design” issue: things in the world, especially living things, behave and seem to be the result of a plan, which leads us to the idea of a planner or designer. This argument is so strong that has inspired Reverend William Paley in his $19^{\text {th }}$-century best-seller, Natural Theology, which introduces the metaphor of God as a watchmaker, properly destroyed by Dawkins in a book published in 1986, The blind watchmaker.

The success of that argument is such that, until today, the main rhetorical tool of creationists, a heterogeneous group of fundamentalists from different Abrahamic religions Islamism, Catholicism and Protestantism - who defend that the existence of life, of human beings 
and especially of the human mind cannot be a product of non-intelligent processes, such as evolution through natural selection, and are unarguably a product of a creative intelligence.

The main supporter and modernizer of creationist theses in the academic circle is the biochemist Michael Behe, author of Darwin's black box, ${ }^{5}$ which has previously been severely criticized by Dawkins. This time, as described in detail in The God delusion, Behe has suffered a major legal setback in a controversial law suit brought by students’ parents who were opposed to the teaching of "intelligent design" (name given to the most modern version of creationism) in public schools, obtaining, by the end of 2005, a favorable verdict.

“The teaching of 'intelligent design' is a breathtaking stupidity,” stated the judge responsible for the case and, to preserve the separation of church and state in accordance with the American federal and state constitutions, prohibited the teaching of creationist ideas in science classes in Dover, Pennsylvania. Behe witnessed as an expert and was submitted to many technical embarrassments, such as the empathic judge's conclusion by declaring that, despite all efforts made by their supporters, "intelligent design” is not science and cannot be dissociated from its religious foundations. ${ }^{6}$

In the list of arguments in favor of divine existence analyzed by Dawkins, there is another one that deserves to be stressed: the argument of personal experience. Many people believe in a divinity, as they believe they had a vision of it, that it directly spoke to them or that they had a transcending experience of intimate contact. It is a strong argument for their supporters, but not enough for third parties, especially those with some knowledge on psychology. Dawkins reports a case of a rapist who received orders from Jesus to kill women; he mentions the American president George W. Bush, who supposedly declared that God had told him to invade Iraq; and he comments that psychiatric hospitals are full of people who think they are other people. They think they can read minds or believe that the whole world conspires against them. Finally, he quotes the philosopher and writer Sam Harris: 
"We have names for people who have many beliefs for which there is no rational justification. When their beliefs are extremely common, we call them 'religious'; otherwise, they are likely to be called 'mad,' 'psychotic' or 'delusional'... Clearly there is sanity in numbers”. 7

\section{WHY ARE WE A RELIGIOUS SPECIES?}

In biological studies of religiousness, one of the aspects in which there is less consensus is about which, among three hypotheses, is the most relevant to explain why religiousness has spread across all human cultures. The most obvious model is that of a direct selective advantage. Abrahamic religions, for example, encourage reproduction quite emphatically. Whether because it increases the adaptation of genes that predispose to a religious brain, whether due to the effect of religious education, there is an adaptive value, in its Darwinian sense, of religious belief.

A second model emphasizes group selection. It refers to the idea that acquiring a religion or belief does not increase the individual's adaptive value in relation to other group members, but increases the survival rates of their group in relation to other groups that do not have that characteristic. A belief in a protecting and demanding God, for instance, increases group cohesion and the ability of resisting environmental stressing factors.

However, Dawkins' option is for the third model, which holds that the religious behavior can be explained as a subproduct of other mental characteristics that are not directly linked to the religious experience. It is not a new idea, but in The God delusion there are some original ideas that can be submitted to empirical tests, based on the development of children's thinking. For Dawkins, children are intuitively "theist," since their minds are prepared to identify a planning in the functioning of the world. For example, why are clouds for? Or sharp rocks serve for animals scratching themselves when they have an itch. Children, therefore, are congenital teleologists, and some are not able to abandon this stage when they grow up.

Perhaps the most inspiring aspect in Dawkins’ new book is the desire to demystify the prejudice against religious beliefs as bringing a special status, which avoids polite people from 
discussing the rational and irrational aspects of other people's religions. A quotation by journalist H. L. Mencken (1880-1956) is very appropriate: "We must respect the other fellow's religion, but only in the sense and to the extent that we respect his theory that his wife is beautiful and his children smart.”

Atheists are not worse neither better than religious people, despite Hitler and Stalin being often mentioned as examples of atheist evil. Stalin was unarguably an atheist, probably because he studied in a seminar when he was a child, but there are doubts about Hitler's position. In many texts, he declared himself a Catholic. A Catholic, doubtlessly, was Pope Pius XII, who persistently refused to maintain a position against the Nazis, which created an embarrassing situation for the contemporary Catholic church. Saddam Hussein* and Osama bin Laden are also religious people.

* Editors’ Note: this book review was written before Saddam Hussein’s hanging.

\section{REFERENCES}

1. Dawkins R. The emptiness of theology. Disponível em: http://www.simonyi.ox.ac.uk/dawkins/WorldOfDawkinsarchive/Dawkins/Work/Articles/emptiness_of_theology.shtml.

2. Dawkins R. Religion's misguided missiles - promise a young man that death is not the end and he will willingly cause disaster. Disponível em: http://www.guardian.co.uk/wtccrash/story/0,,552388,00.html.

3. Dawkins R. The selfish gene. Oxford: Oxford University Press; 1976.

4. Dawkins R . The blind watchmaker: why the evidence of evolution reveals a universe without design, 1986 . New York: WW Norton; 1986.

5. $\quad$ Behe M. A caixa preta de Darwin. Rio de Janeiro: Jorge Zahar. 1996.

6. Kitzmiller V. Dover Area School District - Dover, Pennsylvania Intelligent Design Case Available from: http://www.talkorigins.org/faqs/dover/kitzmiller_v_dover.html. 
7. Harris S. The end of faith: religion, terror and the future of reason. New York: WW Norton; 2004.

Correspondence:

Renato Zamora Flores

Departamento de Genética - Instituto de Biociências - UFRGS

Av. Bento Gonçalves, 9500, Prédio 43323, Sala 109

Caixa Postal 1503

CEP 91501970 - Porto Alegre, RS, Brazil 